\title{
APLICABILIDADE DA LEI DE IMPROBIDADE ADMINISTRATIVA AOS AGENTES POLÍTICOS
}

\author{
Ana Carolina Guarino Duarte da Silva Backer ${ }^{1}$
}

\section{Resumo}

O presente Trabalho de Conclusão de Curso tem por objetivo a elaboração de um artigo científico, requisito obrigatório para conclusão do Curso de Especialização em Direito Público, da Escola Superior da Magistratura Federal no Rio Grande do Sul, em convênio com a Universidade de Caxias do Sul. O tema central da presente pesquisa cinge-se à aplicabilidade do regime de responsabilização por improbidade administrativa previsto na Lei n. 8.429/1992 aos agentes políticos. No Brasil, a corrupção e a imoralidade estão impregnados de tal forma na Administração Pública, que se exige um modelo mais rígido de responsabilização com o fim de proteção à probidade administrativa e garantia do direito fundamental ao governo honesto. Nesse contexto, desenvolveu-se o presente trabalho em torno do sistema de responsabilização por improbidade administrativa, buscando responder ao problema proposto, consistente na possibilidade de incidência da Lei de Improbidade Administrativa aos agentes políticos. Dessa forma, o objetivo principal da pesquisa reflete a importância de um modelo rígido de responsabilização a fim de coibir o mau uso da "coisa pública". Para tanto, utilizou-se o método de pesquisa dedutivo, com uma abordagem qualitativa e teórica e tendo como alicerce a revisão bibliográfica da doutrina e jurisprudência sobre o tema. A divisão dos capítulos deu-se da seguinte maneira: o primeiro intitulado, regime sancionatório por improbidade administrativa como concretização dos princípios da moralidade e probidade administrativa e do ideal republicano na sanção por improbidade administrativa; o segundo: sistema de responsabilização por ato de improbidade administrativa; e o terceiro: esferas de responsabilização dos agentes políticos e implicações da aplicação da lei de improbidade administrativa aos agentes políticos. Assim, conclui-se que é plenamente possível o duplo regime de responsabilização incidentes quanto aos agentes políticos, tanto a título de infrações político-administrativas, quanto por atos de improbidade, na medida em que existe uma dupla normatividade no tratamento dessas infrações. Quanto à competência para processamento das ações de improbidade administrativa, no que concerne à prerrogativa de foro, percebeu-se que não há uma resposta ideal, de forma que a solução mais 
acertada seria a previsão em sede constitucional, como forma de legitimar a sua incidência.

Palavras-chave: Improbidade administrativa. Crimes de responsabilidade. Agente político. Prerrogativa de função.

\section{Introdução}

O Brasil possui um longo histórico de desvirtuamento do funcionalismo público, marcado pela apropriação desenfreada de bens e riquezas de caráter público, evidenciando a corrupção como uma praga, impregnada na Administração Pública Brasileira².

A sensação de impunidade permeia a sociedade, de modo que se busca, a qualquer custo, aumentar as formas de responsabilização com o intento de coibir excessos e imoralidades desses sujeitos que deveriam atuar em nome do povo.

Como meio de resposta a essa insatisfação, num movimento já denominado por alguns como "As Jornadas de Junho"3 , a população brasileira foi às ruas no ano de 2013 a fim de protestar em defesa de diversas bandeiras - por mais saúde e educação, contra aumento de tarifa do transporte público - mas, sobretudo, compartilhavam forte indignação com a corrupção política em geral.

Contudo, referida responsabilização não pode deixar de estar respaldada no ideal de Estado Democrático de Direito, respeitando, como regra mor, a Carta Magna e os princípios ali sedimentados, em especial a moralidade, a probidade administrativa e a ordem republicana, cujo elemento essencial é a consagração da ideia de responsabilidade dos agentes estatais.

Nesse contexto, o objetivo do presente estudo é discutir, sem a pretensão de esgotar, a aplicabilidade da lei de improbidade administrativa aos agentes políticos, mediante a análise do entendimento doutrinário e jurisprudencial atinente ao tema, abordando as principais implicações da adoção desse entendimento.

Inicia-se, portanto, por uma abordagem principiológica, a partir do exame da disciplina normativa das sanções por improbidade administrativa como elemento de densificação dos princípios da moralidade e da probidade administrativa, ressaltando sua importância e sua caracterização como direito fundamental do cidadão. Além disso, tratar-se-á do regime de responsabilização dos agentes estatais como expressão do ideal republicano. 
A seguir, a partir da análise das diversas teorias sobre a natureza jurídica do ato de improbidade administrativo, bem como do conceito legal de sujeito ativo do ato de improbidade e do termo doutrinário "agente político", passa-se ao tema central do estudo concernente à incidência da lei de improbidade administrativa a essa categoria.

$\mathrm{E}$, ao final, serão analisadas as principais implicações da adoção desse regime de responsabilidade, em especial a competência para julgamento das ações de improbidade administrativa intentadas em face dos agentes políticos e a necessidade de observância de prerrogativa de função.

Em conclusão, registra-se que há certa divergência sobre o tema, o que por si só serve de justificativa à pesquisa. Além disso, tem-se a necessidade de resposta à sociedade no que concerne a esse crescimento desmedido da corrupção, o que exige um modelo mais rígido de responsabilização com o fim último de proteção à probidade administrativa e garantia do direito fundamental ao governo honesto.

Por fim, deve ser ressaltado que, quanto à metodologia empregada na presente pesquisa, utilizar-se-á o método de abordagem dedutivo, buscando amparo bibliográfico, tanto nos melhores doutrinadores que tratam do tema, quanto em julgados dos Tribunais Superiores acerca do assunto, abordando as teses divergentes e as principais controvérsias existentes.

A investigação refletirá, ainda, uma abordagem qualitativa e teórica, além de prescritiva, na medida em que buscará propor um modelo teórico ideal para a solução do problema. Por outro lado, no que tange aos procedimentos técnicos se desenvolverá levando em conta a revisão bibliográfica e a pesquisa jurisprudencial.

\section{Regime sancionatório por improbidade administrativa como concretização dos princípios da moralidade e probidade admi- nistrativa e do ideal republicano}

O regime de responsabilização dos agentes públicos por improbidade administrativa encontra respaldo na Constituição Federal de 1988 que, no capítulo atinente à Administração Pública, mais precisamente no artigo 37, § $4^{\circ}$, expressamente prevê:

Os atos de improbidade administrativa importarão a suspensão dos direitos políticos, a perda da função pública, a indisponibilidade dos bens e o ressarcimento ao erário, na forma e gradação previstas em lei, sem prejuízo da ação penal cabível. 
Para a análise desse tema é imprescindível uma abordagem inicial principiológica. Nesse tocante, aliás, Juarez Freitas ressalta a necessidade de se nortear em função dos princípios fundamentais, para além das regras, haja vista a superioridade axiológica daqueles, servindo-lhes estas tão somente à sua densificação $0^{4}$.

Nesse sentido, segundo os ensinamentos de Gilmar Mendes, o dispositivo supracitado nada mais é senão elemento de densificação do princípio da moralidade, que não obstante sua amplitude e pouca densidade jurídica, apoiado em outros parâmetros - como a proporcionalidade para sua maior concretização, serve de fundamento à atuação administrativa, funcionando como balizamento no controle do ato administrativo ${ }^{5}$.

Diante da importância da moralidade administrativa, Carmen Lúcia Antunes chega a considerá-la direito público subjetivo do cidadão, na medida em que "todo cidadão tem direito a um governo honesto".

Por outro lado, complementando essa ideia, José Rubens Plates considera que o direito a um governo honesto, com o avanço da teoria dos direitos fundamentais e do próprio Direito Administrativo, deixou de ser reconhecido como apenas direito subjetivo, restrito à ideia de mera faculdade do indivíduo, passando a ser considerado direito fundamental de natureza difusa. Nesse sentido, complementa que "não se trata de faculdade específica ou determinada, mas sim de um complexo de direitos e garantias que reúne todas as prerrogativas que o indivíduo tenha para poder exigir a probidade e a lisura na administração pública" ${ }^{\text {. }}$

A justificar a caracterização do direito ao governo honesto como direito fundamental, Wallace Paiva Martins Júnior argumenta que

Por dimensão estrutural, a moralidade administrativa é um valor socialmente difundido e, por isso, pertence a toda a coletividade, indivisível e indeterminadamente, integrando o patrimônio social, como pondera Lúcia Valle Figueiredo, garantindo o direito subjetivo público a uma Administração Pública honesta, pois, na medida em que se estabelece e se desenvolve, impõe limites e apresenta redutores à discricionariedade administrativa, ao desvio de poder, à desonestidade, à deslealdade, implantando uma rede de proteção ética destinada à sublimação das regras de boa administração.

$[\cdots]$

A proteção jurídica brasileira dos direitos e interesses metaindividuais abrange a tutela da moralidade e da probidade administrativas. A moralidade administrativa é considerada interesse difuso por excelência, cujo titular é a coletividade. A probidade, dever decorrente da 
moralidade, segue a mesma natureza (indivisibilidade e indisponibilidade) e tem a mesma titularidade.

Desse modo, por possuir natureza difusa, o direito ao governo honesto tem características de direito fundamental de terceira geração/ dimensão (direitos de solidariedade ou de fraternidade). Pode ser defendido em juízo tanto coletiva como individualmente ${ }^{8}$.

Do referido princípio descende, ainda, a ideia de probidade administrativa que consiste, segundo os ensinamentos de Juarez Freitas, na

proibição de atos inequivocamente desonestos ou desleais para com o Poder Público, praticados por agentes seus ou terceiros, concretizado por tipificações e mecanismos sancionatórios inscritos na Lei n. 8.429/92, que exigem aplicação cercada das devidas cautelas para não transpor os limites finalísticos traçados pelo próprio princípio ${ }^{9}$.

A respeito da relação entre moralidade e probidade administrativa, ensina José Afonso da Silva que esta última

é uma forma de moralidade administrativa que mereceu consideração especial pela Constituição, que pune o ímprobo com a suspensão dos direitos políticos (art. 37, $\S 4^{\circ}$ ). A probidade administrativa consiste no dever de o "funcionário servir a Administração com honestidade, procedendo no exercício de suas funções, sem aproveitar os poderes ou facilidades delas decorrentes em proveito pessoal ou de outrem a quem queira favorecer". Cuida-se de uma imoralidade administrativa qualificada. A improbidade administrativa é uma imoralidade qualificada pelo dano ao erário e correspondente vantagem ao ímprobo ou a outrem ${ }^{10}$.

Diante da importância do tema, aliás, Mateus Siqueira defende a existência de um verdadeiro microssistema de proteção à probidade administrativa, antítese da improbidade e alçado à categoria de direito fundamental. Para tanto, argumenta que

mais do que simples regulamentação da norma constitucional, a Lei criou um complexo modelo de proteção da probidade administrativa, alterando significativamente o Direito Administrativo brasileiro, de modo a ampliar o seu caráter sancionador.

Anteriormente, esse ramo do Direito se restringia à punição disciplinar, pela via do processo administrativo, movido contra os seus servidores autores de infrações disciplinares, terceiros que firmassem e descumprissem relações contratuais com a Administração Pública e demais administrados sujeitos ao poder de polícia do Estado, processo esse de alcance restrito em nosso sistema jurídico e sujeito à revisão judicial ${ }^{11}$. 
É nesse contexto que a moralidade e a probidade administrativa servem de pressuposto de validade dos atos administrativos. Sobre o assunto, afirma Gilmar Mendes que, a partir da constitucionalização desses princípios, já não basta ao administrador cumprir formalmente a lei, o que alarga o controle do Poder Judiciário sobre a atuação da Administração ${ }^{12}$.

Contudo, a ideia de improbidade não se restringe à imoralidade. É o que defende Emerson Garcia e Rogério Pacheco Alves, de modo que não há que se limitar a noção de improbidade a de imoralidade, haja vista ser aquela muito mais ampla a ponto de abranger outros princípios administrativos. Desse modo, embora a moralidade seja elemento essencial ao conceito de improbidade administrativa, não é restrito a essa ideia, o que implica conceber que a amplitude de improbidade não está restrita, tampouco delimitada pela da imoralidade ${ }^{13}$.

Além disso, a necessidade de responsabilização dos agentes públicos e o direito ao governo honesto também decorrem do princípio republicano, inscrito no artigo $1^{\circ}$, caput, da Constituição Federal ${ }^{14}$, com o objetivo de afastar em definitivo os ideais monárquicos de irresponsabilidade estatal, pautado na máxima the king can do no wrong ${ }^{15}$. Nesse sentido, vale a lição de Geraldo Ataliba:

é da essência do regime republicano que quem quer que exerça uma parcela do poder público tenha a responsabilidade desse exercício; ninguém desempenha funções políticas por direito próprio; nele, não pode haver invioláveis e irresponsáveis, entre os quais exercitam poderes delegados pela soberania nacional ${ }^{16}$.

É possível então concluir que, no Estado republicano, os agentes públicos são gestores da "coisa pública", não estando imunes ao Direito, razão pela qual devem ser responsabilizados pelos danos a que derem causa, de forma que o ideal republicado se constitui em fundamento último de todo o sistema de responsabilidade consagrado na Constituição Federal ${ }^{17}$. Nessa linha, especificamente quanto à improbidade, José Roberto Pimenta Oliveira afirma que

deriva do princípio republicano a imposição de responsabilidade dos agentes públicos. Em rigor técnico, todos os sistemas de controle e responsabilização que incidem sobre a atuação do Estado e de seus agentes asseguram, reiteram, reforçam e densificam o princípio republicano, demonstrando sua alocação nos alicerces do sistema constitucional. Aqui incluído o sistema da improbidade ${ }^{18}$.

Nesse cenário, é possível afirmar que a ampla responsabilização dos agentes públicos prevista na Constituição Federal, em especial no artigo 
$37, \S 4^{\circ}$, decorre diretamente da eficácia imperativa conferida aos princípios constitucionais, especialmente no que diz respeito aos princípios republicanos da moralidade e da probidade administrativa.

\section{Sistema de responsabilização por ato de improbidade adminis- trativa}

O principal instrumento de defesa da probidade e da moralidade administrativa, conferindo concretude ao sistema de responsabilização dos agentes públicos, é a Lei n. 8.429/1992, que trata do rito da ação por improbidade administrativa.

Vale ressaltar que o constituinte brasileiro, ao estatuir um regime sancionatório para os atos atentatórios ao dever de probidade, fez decisiva opção por um tratamento severo e específico, compatível com a gravidade decorrente da frustração do objetivo de assegurar plenamente os direitos fundamentais ${ }^{19}$.

Nesse contexto, a interpretação da Lei n. 8.429/1992, deve ser realizada de forma igualmente abrangente, sob pena de tornar ineficazes as previsões constitucionais.

\subsection{Natureza jurídica do ato de improbidade administrativa}

Determinar a natureza jurídica do ato de improbidade administrativa é essencial para especificar o sistema sancionatório aplicável, sobretudo para se evitar dupla punição pelo mesmo fato e sob a mesma esfera de responsabilização.

Fernando Capez alerta sobre a diferenciação entre a natureza jurídica da ação de improbidade administrativa e aquela relativa a atos dessa espécie. Enquanto a ação é indubitavelmente de natureza cível, o ato seria um quarto gênero de ato ilícito, ao lado dos aspectos civil, penal e administrativo ${ }^{20}$.

Seguindo essa mesma linha, o ato de improbidade pode ser conceituado como uma infração ético-jurídica aos postulados administrativos, de forma que não é possível categorizá-la em qualquer das esferas usuais de ato ilícito ${ }^{21}$. Orivaldo Bernardes de Oliveira Netto bem resume essa ideia, admitindo a responsabilização pela prática de um ato ilícito, em quatro esferas diversas: 
na civil, por ser decorrência de um princípio geral do direito; na penal, caso haja adequação típica; na administrativa, se porventura traduza infração funcional, ou política, reservada aos agentes políticos com julgamento perante o Poder Legislativo (os chamados crimes de responsabilidade); e na esfera da improbidade administrativa, caso o mesmo fato revele violação ético-jurídica aos preceitos previstos nos arts. $9^{\circ}$ a 11 da Lei n. 8.429/1992 ${ }^{22}$.

Adotando esse mesmo entendimento, José Roberto Pimenta Oliveira defende a autonomia constitucional da esfera de responsabilidade jurídica relativa à improbidade administrativa, haja vista esta não se enquadrar em nenhum dos três sistemas de responsabilização costumeiramente abordados na doutrina (civil, penal e administrativo) ${ }^{23}$.

De igual modo, há certa divergência quanto à natureza da sanção por improbidade administrativa, que Ricardo Fernandes bem sintetiza:

são quatro correntes doutrinárias, quais sejam: (i) a majoritária e adotada pela grande maioria dos administrativistas de que as sanções previstas na Lei Geral de Improbidade Administrativa têm caráter civil; (ii) a que reconhece o caráter civil das sanções previstas na Lei Geral de Improbidade Administrativa, porém, excepciona que nos casos das sanções de suspensão de direitos políticos e de perda da função pública, estaríamos diante de ação "civil", mas de forte conteúdo penal; (iii) a que busca no direito administrativo sancionador o fundamento jurídico para justificar que as sanções do ilícito de improbidade têm natureza administrativa; e (iv) uma quarta corrente em que a natureza jurídica das sanções na ação por ato de improbidade administrativa seria penal, pelos graves efeitos decorrentes da aplicação de tais sanções, aproximados de uma jurisdição penal ${ }^{24}$.

Nesse contexto, é necessário diferenciar a natureza jurídica das sanções por improbidade administrativa e a eventual aplicação dos princípios norteadores do Direito Penal. É certo que não é o resguardo de certas garantias inerentes ao Direito Sancionador que implicará em necessário caráter penal dessas sanções. E por esse motivo, malgrado defender a natureza extrapenal dessas penalidades, Emerson Garcia faz ressalva quanto à observância dos princípios básicos norteadores do Direito Penal, sabidamente mais gravoso para o indivíduo, haja vista também se tratar de expressão do Direito sancionador do Estado ${ }^{25}$.

Fábio Konder Comparato também renega o caráter penal da demanda por improbidade administrativa sob a justificativa de que se "a própria Constituição distingue e separa a ação condenatória do responsável por atos de improbidade administrativa às sanções por ela expressas, da 
ação penal cabível, é, obviamente, porque aquela demanda não tem natureza penal"26. E, no mesmo sentido, sintetiza Maria Sylvia Zanella Di Pietro:

a) o ato de improbidade, em si, não constitui crime, mas pode corresponder também a um crime definido em lei; b) as sanções indicadas no artigo 37 , $\S 4^{\circ}$, da Constituição não tem a natureza de sanções penais, porque, se tivessem, não se justificaria a ressalva contida na parte final do dispositivo, quando admite a aplicação das medidas sancionatórias nele indicadas "sem prejuízo da ação penal cabível"; c) se o ato de improbidade corresponder também a um crime, ação da improbidade pela ação cabível será concomitante com o processo criminal ${ }^{27}$.

Não obstante, parte minoritária da doutrina, embora defenda a natureza cível, ressalta um forte conteúdo de natureza criminal dessas penalidades, a exemplo de Arnoldo Wald e Gilmar Mendes que defendem:

A simples possibilidade de suspensão de direitos políticos, ou a perda da função pública, isoladamente consideradas, seriam suficientes para demonstrar que não se trata de uma ação qualquer, mas de uma "ação civil" de forte conteúdo penal, com incontestáveis aspectos políticos.

[..] É evidente, pois, que, tal como anotado pela doutrina, a sentença condenatória proferida nessa peculiar "ação civil" é dotada de efeitos que, em alguns aspectos, superam aqueles atribuídos à sentença penal condenatória. É certo, pois, que a condenação proferida na ação civil de que trata o art. 37, § 40, da Constituição poderá conter, também, efeitos mais gravosos para o equilíbrio jurídico-institucional do que eventual sentença condenatória de caráter penal ${ }^{28}$.

Com a devida vênia aos defensores da natureza penal do ato de improbidade administrativa, resta claro que os atos de improbidade administrativa têm uma natureza sui generis, prova disso, aliás, é que o Constituinte originário privilegiou seu tratamento, diferenciando-o expressamente da seara penal.

\subsection{Sujeito ativo do ato de improbidade administrativa}

Entre outras matérias, a Lei n. 8.429/1992 determina quais pessoas estão sujeitas à incidência desse modelo de responsabilização. Assim dispõe o artigo $2^{\circ}$ do referido diploma legislativo:

reputa-se agente público, para os efeitos desta lei, todo aquele que exerce, ainda que transitoriamente ou sem remuneração, por elei- 
ção, nomeação, designação, contratação ou qualquer outra forma de investidura ou vínculo, mandato, cargo, emprego ou função nas entidades mencionadas no artigo anterior ${ }^{29}$.

Alargando esse conceito, Celso Antônio Bandeira de Mello ensina que a expressão "agentes públicos" deve ser tomada em uma acepção mais ampla possível a fim de contemplar genérica e indistintamente qualquer sujeito que serve ao Poder Público como instrumento de sua vontade ou ação, ainda que esporadicamente ${ }^{30}$. No que tange especificamente ao agente político, segundo a classificação de Maria Sylvia Zanella Di Pietro, este é espécie do gênero agente público ${ }^{31 .}$

Quanto à concepção de agente político, há duas posições, uma mais ampla - defendida por Hely Lopes Meirelles ${ }^{32}$; outra, mais restritiva, compartilhada por Celso Antônio Bandeira de Mello e Maria Sylvia Zanella Di Pietro.

Assim, considerando o conceito legal - bastante abrangente -, além da classificação doutrinária na qual agente político é espécie do gênero agente público, ao menos em princípio, os agentes políticos estariam incluídos na esfera de Incidência da Lei de Improbidade Administrativa, podendo figurar como sujeito passivo de eventual ação.

Complementando essa ideia, Orivaldo Bernardes de Oliveira Netto salienta:

embora não tenha utilizado a expressão agente político, percebe-se que o conceito está contemplado na ampla definição de agente público, notadamente porque a lei faz alusão expressa àquele que exerce função, cargo, mandato, emprego, perante os entes de Administração Direta e Indireta, seja por eleição, seja por nomeação, designação, ou qualquer forma de investidura ou vínculo.

[...] A mens legis, por certo, não tinha nenhuma intenção de retirar os agentes políticos da esfera de abrangência da lei regulamentadora da Constituição, que previa severas punições àqueles que praticassem improbidade administrativa, e cujo escopo visava à responsabilização de todos aqueles que pudessem praticar atos lesivos ao patrimônio público ou dele se favorecessem, ainda que não redundassem em efetivo dano pecuniário ${ }^{33}$.

Aliás, é certo que o constituinte, seguido pelo legislador ordinário, utilizaram-se de conceitos bem amplos, a fim de abarcar as mais variadas situações, de modo que é vedado ao intérprete restringir esses conceitos, sob pena da ineficácia do próprio instituto. 
4 Esferas de responsabilização dos agentes políticos e implicações da aplicação da lei de improbidade administrativa aos agentes políticos

Especificamente acerca da possibilidade de o agente político ser sujeito ativo do ato de improbidade administrativa, disciplinada na Lei $\mathrm{n}$. 8.429/1992, afirma Daniel Amorim Assunção Neves que a celeuma gira em torno da interpretação sistemática do texto constitucional, no que distingue os crimes de responsabilidade e os atos de improbidade administrativa ${ }^{34}$.

Assim, há quem entenda pela defesa de um tratamento diferenciado quanto aos agentes políticos, por conta das peculiaridades intrínsecas à sua condição especial, cujo tratamento está previsto constitucionalmente. Esse é, aliás, o posicionamento de Maria Sylvia Zanella Di Pietro, que, ao discorrer sobre os agentes políticos como sujeitos ativos do ato de improbidade administrativa, ressalta a imunidade parlamentar no que se refere à seara criminal; a impossibilidade de aplicação da sanção de perda da função pública por improbidade administrativa - que apenas pode seguir o procedimento previsto constitucionalmente; além da necessidade de observância da prerrogativa de foro, em especial, quando de competência originária, também com amparo na Constituição Federal de $1988^{35}$. Contudo, registra-se que referida autora, embora teça ressalvas quanto à responsabilização dos agentes políticos, defende a independência de instâncias entre as sanções por improbidade e por crime de responsabilidade, sob o argumento de que não há razão "para que os agentes políticos escapem à regra, até porque, pela posição que ocupam, têm maior compromisso com a probidade administrativa" ${ }^{\prime 3}$.

Outro fundamento adotado a fim de afastar a possibilidade de aplicação da Lei de Improbidade Administrativa, diz respeito à existência de eventual bis in idem nos casos de responsabilização em diferentes esferas, como a penal, civel e administrativa.

Ressalte-se que o art. 37, § 4º, da Constituição Federal de 1988 já citado, faz clara menção à possibilidade de coexistência entre diferentes esferas de responsabilização, individualizando as penas penais e aquelas impostas por ato de improbidade administrativa.

Sobre o assunto, leciona José dos Santos Carvalho Filho:

Cada responsabilidade é, em princípio, independente da outra. Por exemplo, pode haver responsabilidade civil sem que haja responsabilidade penal ou administrativa. Pode também haver responsabili- 
dade administrativa sem que se siga conjuntamente a responsabilidade penal ou civil. Sucede que, em algumas ocasiões, o fato que gera certo tipo de responsabilidade é simultaneamente gerador de outro tipo; se isso ocorrer, as responsabilidades serão conjugadas. Essa é a razão por que a mesma situação fática é idônea a criar, concomitantemente, as responsabilidades civil, penal e administrativa $^{37}$.

Desse modo, conforme já assentado, considerando as quatro diferentes categorias de ato ilícito (civil, penal, administrativa - traduzida na ideia de infração funcional ou política -, e por improbidade administrativa), é certo que cada uma comporta sanções distintas e perfeitamente compatíveis entre si. Nesse sentido, vale trazer a lição de Eurico Bitencourt Neto:

É patente a ampliação do espaço normativo dedicado à probidade administrativa, a partir da Constituição de 1988. Deve-se esclarecer que os atos atentatórios à probidade administrativa, como princípio constitucional - derivado da moralidade administrativa -, vale dizer, os atos que traduzam atuação desonesta e danosa à Administração Pública, podem significar, nos termos do Direito Positivo, responsabilidade civil, criminal, política ou administrativa. O mesmo ato, desde que haja previsão legal, tendo em vista a independência dos âmbitos de responsabilidade, pode culminar em sanções em cada um deles ${ }^{38}$.

Contudo, quanto aos agentes políticos, essa possibilidade de dupla ou tripla responsabilização comporta ainda certa divergência, pois a Carta Magna, não obstante ter previsto expressamente a independência da ação penal, silenciou no que tange à possibilidade de cumulação quanto à responsabilização por ato de improbidade administrativa e por crime de responsabilidade.

Nesse diapasão, Gina Copola entende que apenas a Lei de Crimes de Responsabilidade - Lei n. 1.079/1950 - poderia ser aplicada aos agentes políticos, em detrimento da Lei de Improbidade Administrativa, uma vez que não é justificável que ambos os diplomas incidam sobre o mesmo agente, pelos mesmos atos ${ }^{39}$.

De modo diverso, a quase unanimidade da doutrina defende a plena incidência do regime ditado pela Lei de Improbidade Administrativa (LIA) aos agentes políticos, comportando apenas pequena divergência quanto à integralidade de sua aplicação. 
Celso Antônio Bandeira de Mello segue esse raciocínio e defende que

a norma revela o mais explícito, consciente e deliberado intento de colocar sob seu âmbito de regência tanto os sujeitos relacionados ao Poder Público ou a suas entidades auxiliares por vínculos de trabalho profissional quanto os que a eles se vinculam por liames de caráter político. É que falou também em "eleição, mandato, designação". Espancou, dessarte, qualquer possibilidade de acrobacia ou malabarismo exegético que pudesse ser forjicado para restringir a noção (já por si mesmo ampla) de agente público e permitir aos agentes políticos que escapulissem dos rigores da lei. ${ }^{40}$

Nessa mesma linha, Emerson Garcia e Rogério Pacheco explicam que os "atos de improbidade administrativa" e os "crimes de responsabilidade" coexistem e não consubstanciam bis in idem, vez que ensejam sanções diversas, por vezes aplicadas em esferas distintas (política e judicial). Além disso, a própria Constituição Federal trata as duas figuras como distintas, remetendo a regulação à legislação infraconstitucional ${ }^{41}$.

\section{Corroborando essa ideia, expõe Wallace Paiva Martins Júnior:}

Mercê de o Supremo Tribunal Federal ter assentado que "os atos de improbidade administrativa são tipificados como crime de responsabilidade na Lei n. 1.079/1950, delito de caráter político-administrativo [...] o sistema constitucional brasileiro distingue o regime de responsabilidade dos agentes políticos dos demais agentes públicos. A Constituição não admite a concorrência entre dois regimes de responsabilidade político-administrativa para os agentes políticos: o previsto no art. 37, $\S 4^{\circ}$ (regulado pela Lei n. 8.429/1992) e o regime fixado no art. 102, I, c (disciplinado pela Lei n. 1.079/1950)", julgou que "a lei 8.429/1992 regulamenta o art. 37, parágrafo $4^{\circ}$ da Constituição, que traduz uma concretização do principio da moralidade administrativa inscrito no caput do mesmo dispositivo constitucional. As condutas descritas na lei de improbidade administrativa, quando imputadas a autoridades detentoras de prerrogativa de foro, não se convertem em crimes de responsabilidade". E vem prestigiando essa última orientação"' porque a tese contrária não tem efeito vinculante e a condição de agentes políticos não os exonera do dever de probidade nem os exclui da esfera da plena incidência normativa da Lei $n$. $8.429 / 1992$, assinalando que o debate sobre a inaplicabilidade dessa lei aos agentes políticos é matéria infraconstitucional e constitui ofensa indireta à Constituição. ${ }^{42}$

De acordo com esse entendimento, portanto, os atos de improbidade não se chocam com os crimes de responsabilidade, guardando, na verdade, uma relação de justaposição, de forma que, além de explicitarem sistemas próprios de responsabilização, cada esfera guarda um ideal 
sancionatório independente: enquanto o primeiro visa tutelar a probidade na Administração Pública, no campo dos crimes de responsabilidade, busca-se garantir a aplicabilidade e eficácia das instituições conforme a Constituição.

Expressivo defensor dessa tese, José Roberto Pimenta Oliveira aduz:

A similaridade do 'conteúdo político' das sanções por improbidade e por crime de responsabilidade não autoriza ilação no sentido de que os 'agentes políticos' estão salvaguardados da primeira, porque sujeitos ao processo e julgamento das infrações político-constitucionais. Inexiste no sistema republicano adotado pela Constituição Federal restrição à categoria de agente público que possa ser retirado do campo de incidência do regime sancionatório civil. A regra do artigo $37, \S 4^{\circ}$ não contém nenhum elemento autorizatório de qualquer redução do seu raio de alcance subjetivo. A República não admite diferenciação de responsabilidade de agentes públicos, senão as estritamente catalogadas na própria ordem jurídica que a instaura, sobretudo temática afeta ao controle da atuação funcional. Estruturado um sistema vocacionado à tutela direta da probidade no seio da coisa pública, não há como isentar determinados agentes com fulcro na aventada complexidade da situação funcional ou das atribuições de certo agente público republicano ${ }^{43}$.

José dos Santos Carvalho Filho, por sua vez, afirma ser possível a coexistência de ambos os sistemas, mediante a observância de algumas regras, em especial, acerca do não cabimento de sanções de natureza política (perda do cargo, suspensão dos direitos políticos), por serem estas aplicadas em sede de ação penal por crime de responsabilidade ${ }^{44}$.

Esse tema, aliás, já comportou polêmica na jurisprudência do Supremo Tribunal Federal, que na Reclamação n. $2138^{45}$, baseou-se na premissa de que os atos de improbidade, em verdade, consubstanciariam crimes de responsabilidade, sujeitando os agentes políticos apenas à responsabilidade política.

Naquela ocasião, que tratava especificamente acerca da condenação de Ministro de Estado por ato de improbidade administrativa, por maioria apertada (6 votos a 5), entendeu-se que a subordinação a dois regimes (Lei n. 1.079/1950 e n. 8.429/1992), com ilícitos de natureza jurídica idêntica - já que ambos veiculariam delitos político-administrativos - caracterizaria bis in idem, o que é vedado pela nossa ordem constitucional. Dessa forma, seriam aplicáveis as disposições da Lei de Crimes de Responsabilidade por conta de sua especialidade, já que, ao contrário da LIA, aquela se destina exclusivamente a agentes políticos. 
Por ser um caso tão paradigmático, vale colacionar parte da ementa do referido julgado.

O sistema constitucional brasileiro distingue o regime de responsabilização dos agentes políticos dos demais agentes públicos. A Constituição não admite a concorrência entre dois regimes de responsabilização político-administrativa para os agentes políticos: o previsto no art. 37, $\S 4^{\circ}$ (regulado pela Lei n. 8.429/92) e o regime fixado no art. 102, I, 'c' (disciplinado pela Lei n. 1.079/1950). Se a competência para processar e julgar a ação de improbidade (CF, art. $37, \S 4^{\circ}$ ) pudesse abranger também atos praticados pelos agentes políticos, submetidos a regime de responsabilidade especial, terse-ia uma interpretação ab-rogante do disposto no art. 102, I, 'c', da Constituição ${ }^{46}$.

A complementar essa ideia, registra-se trecho do voto do Min. Gilmar Mendes que bem sintetiza a tese vencedora.

A simples possibilidade de suspensão de direitos políticos, ou a perda de função pública, isoladamente consideradas, seria suficiente para demonstrar (...) o forte conteúdo penal, com incontestáveis aspectos políticos" da ação de improbidade. Nesse ponto, seguindo a doutrina, observou-se que "a sentença condenatória proferida nessa peculiar 'ação civil' é dotada de efeitos que, em alguns aspectos, superam aqueles atribuídos à sentença penal condenatória", sobretudo na perspectiva do equilíbrio jurídico-institucional. Tal observação, registrou-se, daria razão àqueles que entendem que, sob a roupagem de ação civil de improbidade, o legislador acabou por elencar, na Lei 8.429/92, uma série de delitos que, teoricamente, seriam crimes de responsabilidade e não crimes comuns ${ }^{47}$.

Impende registrar, por outro lado, que na mesma sessão de julgamento da Reclamação n. 2138 (ocorrida em 13 de junho de 2007), nos autos da Petição n. $3923^{48}$, o Plenário, por unanimidade, lastreado em voto de relatoria do Min. Joaquim Barbosa, adotou a tese da dupla normatividade em matéria de improbidade administrativa.

Vale dizer, repisa-se nestes autos a mesma tese sustentada na Reclamação 2.138. Ou seja, a de que as condutas descritas na lei de improbidade administrativa, quando imputadas a autoridades detentoras de prerrogativa foro, se converteriam em crimes de responsabilidade.

A tese é para mim inaceitável.

Eu entendo que há, no Brasil, uma dupla normatividade em matéria de improbidade, com objetivos distintos: em primeiro lugar, existe aquela específica da lei 8.429/1992, de tipificação cerrada mas de 
incidência sobre um vasto rol de possíveis acusados, incluindo até mesmo pessoas que não tenham qualquer vínculo funcional com a Administração Pública (lei 8.429/1992, art. $3^{\circ}$ ); e uma outra normatividade relacionada à exigência de probidade que a Constituição faz em relação aos agentes políticos, especialmente ao chefe do Poder Executivo e aos ministros de Estado, ao estabelecer no art. 85, inciso V, que constituem crime de responsabilidade os atos do Presidente da República que atentem contra a probidade da administração. No plano infraconstitucional, essa segunda normatividade se completa com o art. $9^{\circ}$ da lei 1.079/195049.

Essa decisão, aliás, reforça a tese de que a situação julgada nos autos da reclamação antes referida era pontual, de modo que não poderia vir a ser estendida a todo e qualquer agente político.

Em severa crítica ao posicionamento adotado pela Corte Suprema no julgamento da Reclamação n. 2138, Emerson Garcia afirma que

é pouco provável que os ministros do Supremo Tribunal Federal desconheçam haver (muita) corrupção no Brasil, o que em muito dificulta a compreensão das razões que o estão levando a desarticular a Lei de Improbidade. Também é difícil imaginar que tenha passado despercebido ao Tribunal o efeito devastador que sua decisão causará em termos de proliferação da corrupção. A explicação é simples: como os altos escalões de poder estarão imunes à Lei de Improbidade, é fácil imaginar que neles será concentrado todo o poder de decisão, sujeitando-os, tão-somente, à responsabilização nas esferas política e criminal, cuja ineficácia não precisa ser lembrada ou explicada ${ }^{50}$.

É importante frisar, ainda, que a jurisprudência do Superior Tribunal de Justiça, discordando do entendimento da Corte Constitucional, sempre entendeu pela coexistência de ambos os regimes de responsabilização, destacando-se decisão de relatoria do Ministro Teori Zavascki ${ }^{51}$, que apenas excetua dessa dupla incidência o Presidente da República, por expressa previsão constitucional.

Ao analisar os precedentes que se seguiram no Pretório Excelso, é possível inferir que a posição adotada na referida decisão dizia respeito a uma situação específica, dentro de determinado contexto, que não pode ser estendida a todo e qualquer caso. Primeiro, porque não abrange os agentes políticos não sujeitos à incidência da Lei n. 1.079/1950, como os prefeitos e governadores, por exemplo. Segundo, porque, em função da natureza jurídica das Reclamações Constitucionais, referido precedente não produziu efeitos erga omnes e nem ensejou efeito vinculante. 
Assim, acompanhando, aliás, a mudança da composição daquele Corte Superior - já que muitos dos adeptos daquela posição já não mais a compõem -, o entendimento adotado no referido precedente não vem sendo repetido. Registra-se que, em diversas oportunidades, em decisões monocráticas e em julgamentos perante os órgãos fracionários daquele Tribunal ${ }^{52}$, o entendimento prevalente se deu em sentido diametralmente oposto à posição vencedora na Reclamação n. 2138.

Em especial, vale tratar destacar a Ação Cautelar n. $3585^{53}$, julgada perante a $2^{\mathrm{a}}$ Turma, cujo relator foi o Ministro Celso de Mello, e que tratou de maneira bem didática a matéria. Nessa decisão, baseado na doutrina sobre o tema, sob o prisma dos postulados da moralidade administrativa e do ideal republicano, entendeu-se pela plena aplicabilidade do regime de punição por improbidade administrativa aos agentes políticos, encampando a tese de dupla normatividade sugerida pelo Ministro Joaquim Barbosa no acórdão já citado, proferido na Petição n. 3923.

Atualmente, porém, referido assunto voltou à pauta. Isso porque, mais uma vez, o Plenário do Supremo Tribunal Federal foi provocado a se manifestar, nos autos da Petição n. 3240, que ainda está pendente de resolução definitiva.

O Relator do processo, Ministro Teori Zavascki, ao proferir seu voto, veiculado através do Informativo n. 768, manteve a linha que vinha adotando quando ocupava o cargo de Ministro do Superior Tribunal de Justiça e defendeu que,

excetuada a hipótese de atos de improbidade praticados pelo Presidente da República, submetidos a regime especial, não haveria norma constitucional que imunizasse os agentes políticos, sujeitos a crime de responsabilidade, de qualquer das sanções por ato de improbidade previstas no art. $37, \S 4^{\circ}$, da $\mathrm{CF}^{54}$.

Ante a mudança na composição da Corte desde o julgamento da Reclamação n. 2138, há uma forte tendência de alteração daquele posicionamento, até porque vários dos "novos" Ministros já externaram posições contrárias à tese vencedora naquele precedente paradigmático.

Passa-se, por fim, a analisar a principal implicação do posicionamento a favor da responsabilização dos agentes políticos por ato de improbidade administrativa - a competência para o processamento da demanda intentada em face dos agentes políticos que gozam de prerrogativa de função. 


\subsection{Foro de prerrogativa de função e ação de improbidade admi- nistrativa}

Fixada a premissa de que os agentes políticos estão sujeitos ao regime de responsabilização por improbidade administrativa, surge a celeuma: a quem compete o processamento e julgamento destas ações? Há incidência da prerrogativa de função? Aliás, toda a controvérsia acerca da aplicabilidade da LIA aos agentes políticos diz respeito à observância ou não do foro privilegiado nessas ações.

Indubitavelmente, a resposta a essas perguntas está diretamente ligada à natureza do ato de improbidade administrativa.

Isso porque a prerrogativa de função é prevista na Constituição Federal apenas quanto aos feitos de natureza criminal. Dessa forma, considerando a ação de improbidade administrativa como feito cível, como é o entendimento que tem prevalecido nos Tribunais Superiores, inaplicável seria a garantia de foro privilegiado. Esse, aliás, foi um dos argumentos adotados pelo Supremo Tribunal Federal para embasar a declaração de inconstitucionalidade da Lei 10.628/2002 que, ao acrescentar dispositivo no Código de Processo Penal, estendeu aos acusados pela prática de ato de improbidade o foro privilegiado da ação penal previsto no texto constitucional.

Nos acórdãos proferidos nas Ações Diretas de Inconstitucionalidade n. $2797^{55}$, de relatoria do Ministro Sepúlveda Pertence, com base no argumento de que não seria dado ao legislador ordinário criar nova hipótese de competência originária sem delegação constitucional, declarou-se a inconstitucionalidade dos $\S \S 1^{\circ}$ e $2^{\circ}$ do art. 84 do Código de Processo Penal, com a redação dada pela Lei n. 10.628/2002, afastando a garantia de prerrogativa de função às ações de improbidade administrativa.

Dessa forma, seguindo essa linha, tem prevalecido na jurisprudência dos Tribunais Superiores o entendimento pela competência do $1^{\circ} \mathrm{grau}$ de jurisdição para processamento e julgamento dessas demandas. Primeiro, por conta da declaração de inconstitucionalidade, de efeito vinculante determinada na ADI n. 2797. Segundo, porque é prevalente a tese que afirma a natureza cível das ações dessa natureza.

Embora, inicialmente, tenha esposado entendimento diverso, é nesse sentido o último precedente da Corte Especial do Superior Tribunal de Justiça sobre o tema, cabendo destacar, da ementa, o seguinte excerto: "a ação de improbidade administrativa deve ser processada e julgada nas 
instâncias ordinárias, ainda que proposta contra agente político que tenha foro privilegiado no âmbito penal e nos crimes de responsabilidade"56 .

De igual sorte, temos vários acórdãos do Supremo Tribunal Federal que encampam essa tese, reafirmando a natureza cível do ato de improbidade administrativa e determinando a competência das instâncias ordinárias para processamento da demanda intentada nos moldes da $\mathrm{LIA}^{57}$. Em sede doutrinária, também prevalece esse entendimento.

Dessa forma, após a análise sistemática das competências delineadas na Constituição da República, é possível constatar que o Poder Constituinte Originário jamais estabeleceu competência originária de qualquer tribunal para julgamento de ações de improbidade administrativa, independentemente do cargo ou função do requerido, [...] Logo, considerando que as ações por ato de improbidade administrativa são espécies do gênero ações civis públicas (coletivas), conclui-se que a competência para processar e julgar o agente ímprobo deve ser assegurada a juiz de primeiro grau (estadual ou federal), em regra, do local do dano, nos termos do art. $2^{\circ}$, da Lei n. $7.347 / 85^{58}$.

Seguindo a mesma corrente, destacam-se Wallace Paiva Martins Júnior ${ }^{59}$, Waldo Fazzio Júnior ${ }^{60}$, Fábio Konder Comparato ${ }^{61}$ e Emerson Garcia que, aliás, faz dura crítica à tentativa de extensão do "privilégio" de prerrogativa de foro às ações de improbidade administrativa.

Outro exemplo é a persistência daqueles que lutam por estender às ações de improbidade o foro por prerrogativa de função previsto na esfera criminal. Acostumados com essa regra de exceção que, a nosso ver, sequer deveria existir em um país que se diz democrático, sonham em transferir à esfera cível a impunidade que assola a seara criminal.

Não que a impunidade também não seja a regra em termos de combate à improbidade, mas, sim, porque os arautos da "tese da prerrogativa" há muito perceberam que são grandes as perspectivas de alteração desse quadro. Pergunta-se: quem deseja a manutenção do status quo, a população ou aqueles que se acostumaram e pensam em institucionalizar a confortável sensação de liberdade que a garantia da impunidade Ihes causa? Alguém seria ingênuo o suficiente para não perceber as conseqüências que a pretendida alteração legislativa causaria no combate à improbidade? Basta afirmar que as investigações e a conseqüente propositura das ações deixariam de ser realizadas por milhares de Promotores de Justiça e Procuradores da República e passariam a ser concentradas nas mãos de alguns poucos Chefes institucionais, diga-se de passagem, escolhidos pelo Chefe do Executivo, o que acrescenta um indesejável 
componente político à estrutura organizacional do Ministério Público - mau-vezo que os defensores da "tese da prerrogativa" teimam em não extirpar62.

Sintetizando, aqueles que defendem o processamento das ações de improbidade nas instâncias ordinárias baseiam-se nos seguintes argumentos: a) natureza cível da ação de improbidade administrativa, de forma que, considerando que não há previsão constitucional de competência originária para processamento dos feitos dessa natureza, que se restringe a processos criminal, a competência caberia ao $1^{\circ}$ grau de jurisdição; b) interpretação restritiva tanto das competências estabelecidas constitucionalmente, quanto das hipóteses de prerrogativa de função por se tratar de um privilégio; c) além da sobrecarga de processos nos Tribunais.

Em posição contrária, há quem defenda a necessidade de garantia da prerrogativa de função nesses casos, dado o forte viés penal presente nas sanções de improbidade. Acerca do tema, argumentam Arnold Wald e Gilmar Mendes que

a instituição de uma "ação civil" para perseguir os casos de improbidade administrativa coloca, inevitavelmente, a questão a respeito da competência para o seu processo e julgamento, tendo em vista especialmente as conseqüências de eventual sentença condenatória que, nos expressos termos da Constituição, além da indisponibilidade dos bens e do ressarcimento ao erário, poderá acarretar a perda da função pública e a suspensão dos direitos políticos do Réu (CF, art. 37, § 40). Não há dúvida aqui, pois, sobre o realce político-institucional desse instituto. A simples possibilidade de suspensão de direitos políticos, ou a perda da função pública, isoladamente consideradas, seriam suficientes para demonstrar que não se trata de uma ação qualquer, mas de uma "ação civil" de forte conteúdo penal, com incontestáveis aspectos políticos. Essa colocação serve pelo menos para alertar-nos sobre a necessidade de que não se torne por pacífica a competência dos juízes de primeira instância para processar e julgar, com base na Lei n. 8.429, de 1992, as autoridades que estão submetidas, em matéria penal, à competência originária de Cortes Superiores ou até mesmo do Supremo Tribunal Federal ${ }^{63}$.

Outro argumento utilizado para justificar essa posição é a adoção da teoria das competências implícitas complementares, tese preconizada por Canotilho, que, em resumo, consiste na admissibilidade de complementação das competências constitucionais através do manejo de instrumentos metódicos de interpretação ${ }^{64}$. 
Nesse sentido, sustentam Artur Ferrari Almeida e Eduardo Ferreira Jordão:

Embora seja correto sustentar que as competências estabelecidas constitucionalmente devam ser interpretadas restritivamente, isso não significa haver vedação total e absoluta de soluções hermenêuticas que conduzam a uma expansão do rol de competências dos órgãos constitucionais para além da literalidade do texto da Constituição Federal. Só se poderia supor uma vedação como esta se a própria Constituição expressamente determinasse que as competências nela previstas são taxativas e que, sob nenhuma hipótese, haveriam de ser ampliadas por via interpretativa. Não é o caso. ${ }^{65}$

Embasado na necessidade de interpretação sistêmica da Constituição e na doutrina das competências implícitas acima referida, essa também foi a linha adotada pelo Ministro Teori Zavascki, relator do acórdão no processo Pet n. 3240, já referido nesse estudo, que se encontra em análise no Plenário do Supremo Tribunal Federal. Na ocasião, conforme excertos veiculados no Informativo n. 768, pontuou que,

embora as sanções aplicáveis aos atos de improbidade não tivessem natureza penal, haveria laços de identidade entre as duas espécies, seja quanto às funções (punitiva, pedagógica e intimidatória), seja quanto ao conteúdo. Com efeito, não haveria diferença entre a perda da função pública ou a suspensão dos direitos políticos ou a imposição de multa pecuniária, quando decorrente de ilícito penal e de ilícito administrativo. Nos dois casos, as consequências práticas em relação ao condenado seriam idênticas.

Do ponto de vista dos direitos fundamentais e do postulado da dignidade da pessoa humana, não pareceria lógico que se investisse o acusado de amplas garantias até mesmo quando devesse responder por infração penal que produziria simples pena de multa pecuniária e se lhe negassem garantias semelhantes quando a infração, conquanto administrativa, pudesse resultar em pena mais severa, como a perda de função pública ou a suspensão de direitos políticos. Ao se buscar consolidar entendimento quanto às regras sobre competências jurisdicionais, os dispositivos da Constituição comportam interpretação sistemática que permite preencher vazios e abarcar certas competências implícitas, mas inafastáveis por imperativo do próprio regime constitucional. Em suma, por entender que essa linha de compreensão também deveria ser adotada em relação ao foro por prerrogativa de função, o relator reconheceu a competência do STF para processar e julgar a ação de improbidade contra o requerido, deputado federal ${ }^{66}$. 
No tocante à garantia da prerrogativa de função nas ações de improbidade administrativa, a tendência é de reafirmação dos precedentes anteriores, muito embora o voto do Ministro Teori Zavascki tenha se dado em sentido contrário.

Conclui-se, portanto, que o principal argumento pela não incidência da prerrogativa de foro é a não previsão constitucional, de forma que não há no ordenamento uma resposta ideal, haja vista que ambas as teses são muito bem construídas.

Dessa forma, a solução mais acertada seria a previsão constitucional do tema, como forma de legitimar a sua incidência, pois é certo que, não obstante a sede da sociedade em acabar com a impunidade, soa um pouco ilógico, no Estado Democrático de Direito, submeter um agente estatal a sanções idênticas (cujas consequências práticas são as mesmas), mas que são impostas em julgamento perante órgãos de grau de jurisdição distinto.

Tecidas essas considerações, à parte a discussão acerca da competência para processamento das ações de improbidade intentadas em face de agentes que gozam de prerrogativa de foro, que é de cunho meramente processual, é certo que estão esses agentes submetidos ao regime previsto na LIA, não havendo dupla penalização em face da Lei de Crimes de Responsabilidade, haja vista se tratarem de atos de natureza totalmente distinta.

Além disso, tem-se a necessidade de resposta à sociedade no que concerne a esse crescimento desmedido da corrupção, o que exige um modelo mais rígido de responsabilização com a finalidade de proteção à probidade administrativa.

Por tudo isso, não é possível afastar a aplicação do regime sancionatório por improbidade administrativa dos agentes políticos. Afinal, justamente por gozarem de posição privilegiada, estão mais suscetíveis a controle e deverão responder com maior severidade por desvios da moralidade administrativa.

\section{Conclusão}

A questão-problema buscou orientar o desenvolvimento do trabalho sobre o prisma de ser possível ou não a incidência das regras sancionatórias por improbidade administrativa aos agentes políticos, em especial, aqueles que gozam de prerrogativa de função perante os Tribu- 
nais Superiores. Para responder à pergunta lançou-se a hipótese positiva para o questionamento, haja vista incidir, no caso de proteção à probidade administrativa, uma dupla normatividade, admitindo a responsabilização tanto por crime de responsabilidade, quanto por ato de improbidade administrativa, já que não compartilham a mesma natureza jurídica.

Seguindo a linha de raciocínio dos autores e jurisprudência apresentadas, abordou-se as teses divergentes para alcançar a solução ideal do problema. Assim, infere-se que, considerar que essas pessoas estejam sujeitas apenas a um ou outro regime de responsabilidade, é tornar ineficaz as previsões constitucionais criadas com vistas à proteção da moralidade administrativa.

Nesse diapasão, tomar como sinônimos, no que tange aos agentes políticos, atos de improbidade administrativa e crimes de responsabilidade, unicamente pela identidade de algumas sanções, e por via de consequência isentar os mais altos mandatários da República da incidência da Lei de Improbidade Administrativa, tende a desrespeitar os ideais republicanos e os princípios da legalidade; da igualdade, na medida em que cria tratamento desigual que a norma constitucional não previu; e, também, da moralidade e probidade administrativa, em total afronta ao direito fundamental de se ter um governo probo e honesto.

Assim, diante de um catastrófico índice de prática de corrupção na Administração Pública, não restam dúvidas acerca da necessidade de fortalecimento de instrumentos repressivos suficientemente rigorosos no combate à improbidade administrativa, de forma que, afastar os agentes políticos - maiores detentores de poder - da esfera de responsabilização, é esvaziar todo o sentido da Constituição.

Pelo exposto, nenhuma razão existe para que os agentes políticos escapem à regra, em flagrante violação da igualdade. Até porque, pela posição que ocupam, têm maior compromisso com a probidade administrativa e estão mais suscetíveis a desvios, sendo razoável que respondam com maior severidade pelas infrações praticadas no exercício de seus cargos.

Os crimes de responsabilidade são e sempre serão sancionados como infrações político-administrativas, vez que, por refletirem instrumentos de estabilidade e eficácia das instituições, receberam especial atenção da Constituição. Contudo, isso não impede a responsabilização desses mesmos agentes por atos de natureza distinta, como os de improbidade administrativa, que, por expressa previsão do art. $37, \S 4^{\circ}$, da Carta Magna, recebem tratamento diferenciado. 
Aliás, outra não pode ser a conclusão, sob pena de restringir o alcance dos dispositivos constitucionais, frustando as expectativas da sociedade em ver responsabilizados os causadores de danos à probidade administrativa.

Por outro lado, quanto à aplicabilidade do foro de prerrogativa de função às ações de improbidade, parece ilógico submeter os mais altos mandatários da República, inclusive o Presidente, sem qualquer distinção quanto ao cargo ocupado, a julgamento perante centenas de Juízes, abrindo espaço, inclusive, para decisões conflitantes e antagônicas em situações semelhantes. Tal situação, aliás, poderia vir a ocasionar um efeito inverso daquele inicialmente pretendido baseado no combate à corrupção, culminando em uma verdadeira crise institucional e no enfraquecimento das instituições democráticas.

Ressalta-se que esse instituto, longe de ser um benefício pessoal, consiste em verdadeira ferramenta constitucional de proteção à própria função exercida, vez que visa a garantir o exercício do cargo ou do mandato, e não a proteger quem o exerce.

Dessa forma, concluiu-se que não há resposta satisfatória no ordenamento, de modo que a solução ideal seria o tratamento do tema em sede constitucional, submetendo também as ações de improbidade às regras da prerrogativa de função, malgrado seu caráter extrapenal.

\section{Referências}

ALMEIDA, Artur Ferrari; JORDÃO, Eduardo Ferreira. A competência especial por prerrogativa de função para ex-agentes públicos: uma análise do julgamento das ADI n. 2.797DF e n. 2.860DF. Revista Brasileira de Direito Público, RBDP, Belo Horizonte. Disponível em: <http://www.bidforum.com.br/bid/ PDI0006.aspx?pdiCntd=52596>. Acesso em: 17 jul. 2015.

ARAUJO, Oliveira Marília. Improbidade administrativa "da aplicação da Lei $n$. 8.429/1992 aos atos praticados por agentes políticos que respondem por crime de responsabilidade. Boletim Científico ESMPU, Brasília, a. 10 - n. 36, p. 79-100 - Edição Especial 2011. Disponível em: <http:// boletimcientifico.escola.mpu.mp.br/boletins/boletim-cientifico-n-36-edicaoespecial-2011/improbidade-administrativa-2212-da-aplicacao-da-lei-n-8-4291992-aos-atos-praticados-por-agentes-politicos-que-respondem-por-crimede-responsabilidade>. Acesso em: 12 jul. 2015.

ATALIBA, Geraldo. República e Constituição. 2. ed. São Paulo: Malheiros, 1998.

BERTONCINI, Mateus Eduardo Siqueira Nunes. O microssistema de proteção da probidade administrativa, constituição e gestão pública. Fórum de 
Contratação e Gestão Pública - FCGP, Belo Horizonte, ano 12, n. 133, jan. 2013. Disponível em: <http://www.bidforum.com.br/bid/ PDI0006.aspx?pdiCntd=84237>. Acesso em: 12 dez. 2014.

BRASIL. Constituição (1988). Constituição Federal. Brasília. Disponível em: <http://www.planalto.gov.br/ccivil_03/constituicao/constituicaocompilado.htm>. Acesso em: 10 dez. 2014.

. Lei n. 8429, de 2 de junho de 1992. Dispõe sobre as sanções aplicáveis aos agentes públicos nos casos de enriquecimento ilícito no exercício de mandato, cargo, emprego ou função na administração pública direta, indireta ou fundacional e dá outras providências. Lei de improbidade administrativa. Brasília. Disponível em: <http://www.planalto.gov.br/CCivil_03/leis/ L8429.htm>. Acesso em: 10 nov. 2014.

. Superior Tribunal de Justiça. Reclamação n. 2.790. Corte Especial. Relator: Ministro Teori Albino Zavascki. Brasília, DF, 2 de dezembro de 2009. Dje., 4 mar. 2010.

. Superior Tribunal de Justiça. Reclamação n. 12.514. Corte Especial. Relator: Ministro Ari Pargendler. Brasília, DF, 16 de setembro de 2013. Dje., 26 set. 2013.

Supremo Tribunal Federal. Reclamação n. 2138. Tribunal Pleno. Relator: Ministro Nelson Jobim. Brasília, DF, 13 de junho de 2007. Dje., 17 abr. 2008.

. Supremo Tribunal Federal. Petição n. 3923. Tribunal Pleno. Relator: Ministro Joaquim Barbosa. Brasília, DF, 13 de junho de 2007. Dje., 26 set. 2008.

Supremo Tribunal Federal. Ação cível originária n. 2356. Decisão Monocrática. Relator: Ministro Carmen Lúcia. Brasília, DF, $1^{\circ}$ de março de 2014. Dje., 18 mar. 2014.

. Supremo Tribunal Federal. Agravo regimental no agravo de instru-

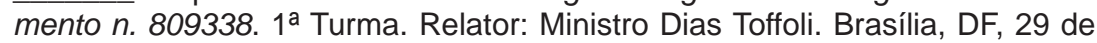
outubro de 2013. Dje., 24 mar. 2014

. Supremo Tribunal Federal. Petição n. 5080. Decisão Monocrática. Relator: Ministro Celso de Mello. Brasília, DF, 28 de junho de 2013. Dje., 0 ago. 2013.

. Supremo Tribunal Federal. Ação cautelar n. 3585. $2^{\mathrm{a}}$ Turma. Relator: Ministro Celso de Mello. Brasília, DF, 2 de setembro de 2014. Dje., 28 out. 2014.

Supremo Tribunal Federal. Ação direta de inconstitucionalidade $n$. 2797. Tribunal Pleno. Relator: Ministro Sepúlveda Pertence. Brasília, DF, 15 de setembro de 2005. Dje., 12 dez. 2006., 
Supremo Tribunal Federal. Agravo regimental em petição n. 3067. Tribunal Pleno. Relator: Ministro Roberto Barroso. Brasília, DF, 5 de agosto de 2014. Dje., 29 ago. 2014.

. Supremo Tribunal Federal. Agravo regimental no recurso extraordinário n. 377114. $1^{\mathrm{a}}$ Turma. Relator: Ministro Marco Aurélio. Brasília, DF, 5 de agosto de 2014. Dje., 29 ago. 2014

Supremo Tribunal Federal. Agravo regimental no agravo de instrumento n. 554398. $1^{\text {a }}$ Turma. Relator: Ministro Ricardo Lewandowski. Brasília, DF, 19 de outubro de 2010. Dje., 16 set. 2010.

Supremo Tribunal Federal. Informativo n. 768. Disponível em: <http:/

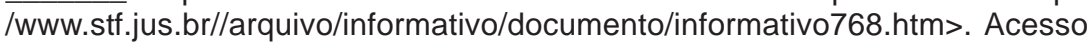
em: 2 mar. 2015.

BITENCOURT NETO, Eurico. Improbidade administrativa e violação de princípios. Belo Horizonte: Del Rey, 2005.

CANOTILHO, José Joaquim Gomes. Direito constitucional e teoria da Constituição. 7. ed. Coimbra-Portugal: Edições Almedina, 2003.

CAPEZ, Fernando. Limites constitucionais à lei de improbidade. São Paulo: Saraiva, 2009.

CARVALHO FILHO, José dos Santos. Manual de Direito Administrativo. 27. ed. São Paulo: Atlas, 2014.

COMPARATO, Fabio Konder. Ação de improbidade: Lei 8.429/92. Competência ao Juízo do $1^{\circ}$ Grau. Disponível em: <http://portal.damasio.com.br/Arquivos/Material/Parecer\%20improbidade.pdf>. Acesso em: 10 jul. 2015.

COPOLA, Gina. Quem pode ser sujeito ativo do ato de improbidade administrativa? (Lei federal n. 8.429/92, art. 20): o enquadramento dos magistrados, dos promotores públicos e dos agentes políticos. Fórum Administrativo Direito Público - FA, Belo Horizonte, ano 8, n. 89, jul. 2008. Disponível em: $<$ http://www.bidforum.com.br/bid/PDI0006.aspx?pdiCntd=54331>. Acesso em: 28 jan. 2015.

FAZZIO JÚNIOR, Waldo. Improbidade administrativa: doutrina, legislação e jurisprudência. São Paulo: Atlas, 2012.

FERNANDES MOÇA, Ricardo Benetti. O retorno da polêmica do foro por prerrogativa de função nas ações por ato de improbidade administrativa. Revista Brasileira de Direito Público - RBDP, Belo Horizonte, ano 11, n. 43, out./dez. 2013. Disponível em: <http://www.bidforum.com.br/bid/ PDI0006.aspx?pdiCntd=98874>. Acesso em: 17 dez. 2014.

FREITAS, Juarez. Princípio da moralidade administrativa. Fórum Administrativo - FA, Belo Horizonte, ano 15, n. 170, abr.2015. Disponível em: <http:// bid.editoraforum.com.br/bid/Default.aspx>. Acesso em: $1^{0}$ jul. 2015. 
GARCIA, Emerson; ALVES, Rogério Pacheco. Improbidade administrativa. 7. ed. São Paulo: Saraiva, 2013.

O combate à corrupção no Brasil: responsabilidade ética e moral do Supremo Tribunal Federal na sua desarticulação. Revista Brasileira de Direito Constitucional, RBDC, n. 10 - jul./dez. 2007. Disponível em: <http:/ /www.esdc.com.br/RBDC/RBDC-10/RBDC-10-383-Emerson_Garcia.pdf>. Acesso em: 18 jul. 2015.

MARTINS JÚNIOR, Wallace Paiva. Probidade administrativa. 3. ed. São Paulo: Saraiva, 2006.

Tratado de Direito Administrativo. v. 2. Coordenado por: Adilson Dallari, Carlos Valder do Nascimento e Ives Gandra Martins. São Paulo: Saraiva, 2013. p. 151.

MIRANDA, Gustavo Senna; COURA. Alexandre de Castro. Extensão do foro por prerrogativa de função às ações de improbidade administrativa. Limites constitucionais para o redimensionamento da competência originária dos tribunais. Revista de Direitos e Garantias Fundamentais da FDV, Vitória, n. 12, dez. 2012. Disponível em: <http://www.fdv.br/sisbib/index.php/ direitosegarantias/article/view/406/150>. Acesso em: 2 mai. 2015.

MEIRELLES, Hely Lopes. Direito Administrativo Brasileiro. 33. ed. São Paulo: Malheiros, 2007.

MELLO, CELSO ANTONIO BANDEIRA DE. Competência para julgamento de agentes políticos por ofensa à Lei de Improbidade Administrativa (Lei n. 8.429, de 2.6.92). Interesse Público IP. Belo Horizonte, n. 42, ano 9, mar./abr. 2007. Disponível em: <http://www.bidforum.com.br/bid/ PDI0006.aspx?pdiCntd=48897>. Acesso em: 17 dez 2014.

2009.

Curso de Direito Administrativo. n. 26. ed. São Paulo: Malheiros,

PLATES, José Rubens. Direito fundamental ao governo honesto. Boletim Científico ESMPU, Brasília, a. 10 - n. 36, p. 79-100 - Edição Especial 2011. Disponível em: < http://boletimcientifico.escola.mpu.mp.br/boletins/boletimcientifico-n-36-edicao-especial-2011/direito-fundamental-ao-governo-honesto>. Acesso em: 12 jul. 2015.

MENDES, Gilmar Ferreira; BRANCO, Paulo Gustavo Gonet. Curso de Direito Constitucional. 9. ed. São Paulo: Saraiva, 2014.

NEVES, Daniel Amorim Assumpção; OLIVEIRA, Rafael Carvalho Rezende. Manual de improbidade administrativa: Direito Material e Processual. 2. ed. São Paulo: Método, 2014.

NETTO, Orivaldo Bernardes de Oliveira. Quem tem medo do Ministério Público? A aplicabilidade da Lei n. 8.429/1992 a agentes políticos. Boletim Científico ESMPU, Brasília, a. 10 - n. 36, p. 79-100 - Edição Especial 2011. Dispo- 
nível em: <http://boletimcientifico.escola.mpu.mp.br/boletins/boletim-cientificon-36-edicao-especial-2011/quem-tem-medo-do-ministerio-publico-aaplicabilidade-da-lei-n-8-429-1992-a-agentes-politicos >. Acesso em: 12 jul. 2015.

OLIVEIRA, José Roberto Pimenta. Improbidade administrativa e sua autonomia constitucional. Belo Horizonte: Fórum, 2009.

PIETRO, Maria Sylvia Zanella Di. Direito Administrativo. 27. ed. São Paulo: Atlas, 2014. 963 p.

ROCHA, Carmen Lúcia Antunes. Princípios constitucionais da administração pública. Belo Horizonte: Del Rey, 1994.

SILVA, José Afonso da. Curso de Direito Constitucional Positivo. 29. ed. São Paulo: Malheiros, 2007.

SOUSA, Cidoval Morais de; SOUZA, Arão de Azevedo (Org.). Jornadas de junho: repercussões e leituras. Campina Grande: Eduepb, 2013.

TRANSPARENCY INTERNACIONAL (Alemanha). Corruption Perceptions Index. 2014. Disponível em: <lhttp://www.transparency.org/ country\#BRA_DataResearch>. Acesso em: 5 jan. 2015.

WALD, Arnold; MENDES, Gilmar Ferreira. Competência para julgar ação de improbidade administrativa. Disponível em: <http://www2.senado.leg.br/bdsf/ bitstream/handle/id/378/r138-17. pdf?sequence=4>. Acesso em: 10 jul. 2015.

\section{Notas}

${ }^{1}$ Analista Judiciário no Tribunal Regional Eleitoral de Santa Catarina. Graduada em Direito pela Universidade Federal de Santa Catarina. Artigo apresentado como requisito obrigatório à conclusão do Curso de Especialização em Direito Público, da Escola Superior da Magistratura Federal no Rio Grande do Sul, em convênio com a Universidade de Caxias do Sul.

${ }^{2}$ Dados recentes divulgados pela Transparência Internacional, em 2014, do Índice de Percepção de Corrupção, que ordena os países a partir do grau de percepção da corrupção no setor público, mostram o Brasil na 69a posição, atrás de diversos países mais "atrasados" economicamente.

${ }^{3}$ SOUSA, Cidoval Morais de; SouZA, Arão de Azevedo (Org.). Jornadas de Junho: Repercussões e leituras. Campina Grande: Eduepb, 2013.

${ }^{4}$ FREITAS, Juarez. Princípio da moralidade administrativa. Fórum Administrativo - FA, Belo Horizonte, ano 15, n. 170, abr. 2015. Disponível em: <http:// bid.editoraforum.com.br/bid/Default.aspx>. Acesso em: 01 jul. 2015.

${ }^{5}$ MENDES, Gilmar Ferreira; BRANCO, Paulo Gustavo Gonet. Curso de Direito Constitucional. 9. ed. São Paulo: Saraiva, 2014, p. 1164. 
${ }^{6}$ ROCHA, Carmen Lúcia Antunes. Princípios constitucionais da administração pública. Belo Horizonte: Del Rey, 1994. p.190.

${ }^{7}$ PLATES, José Rubens. Direito fundamental ao governo honesto. Boletim Científico ESMPU, Brasília, a. 10 - n. 36, p. 79-100 - Edição Especial 2011. Disponível em: <http://boletimcientifico.escola.mpu.mp.br/boletins/boletimcientifico-n-36-edicao-especial-2011/direito-fundamental-ao-governohonesto>. Acesso em: 12 jul. 2015.

${ }^{8}$ MARTINS JÚNIOR, Wallace Paiva. Probidade administrativa. 3. ed. São Paulo: Saraiva, 2006. p.91-94.

${ }^{9}$ FREITAS, Juarez. op.cit.

${ }^{10}$ SILVA, José Afonso da. Curso de Direito Constitucional Positivo. 9. ed. São Paulo: Malheiros, 2007. p. 669.

${ }^{11}$ BERTONCINI, Mateus Eduardo Siqueira Nunes. O microssistema de proteção da probidade administrativa, Constituição e gestão pública. Fórum de Contratação e Gestão Pública - FCGP, Belo Horizonte, ano 12, n.133, jan. 2013. Disponível em: <http://www.bidforum.com.br/bid/ PDI0006.aspx?pdiCntd=84237>. Acesso em: 12 dez. 2014.

${ }^{12}$ MENDES, Gilmar Ferreira; BRANCO, Paulo Gustavo Gonet. op. cit. p. 1165.

${ }^{13}$ GARCIA, Emerson; ALVES, Rogério Pacheco. Improbidade administrativa. 7. ed. São Paulo: Saraiva, 2013. p. 105.

${ }^{14}$ PLATES, José Rubens. op.cit.

${ }^{15}$ Tradução livre da autora: "O rei não erra".

${ }^{16}$ ATALIBA, Geraldo. República e constituição. 2. ed. São Paulo: Malheiros, 1998. p. 61.

${ }^{17}$ ARAUJO, Oliveira Marília. Improbidade administrativa " da aplicação da Lei n. 8.429/1992 aos atos praticados por agentes políticos que respondem por crime de responsabilidade. Boletim Científico ESMPU, Brasília, a. 10 - n. 36, p. 79-100 - Edição Especial 2011. Disponível em: <http:// boletimcientifico.escola.mpu.mp.br/boletins/boletim-cientifico-n-36-edicaoespecial-2011/improbidade-administrativa-2212-da-aplicacao-da-lei-n-8-4291992-aos-atos-praticados-por-agentes-politicos-que-respondem-por-crimede-responsabilidade>. Acesso em: 12 jul. 2015.

${ }^{18}$ OLIVEIRA, José Roberto Pimenta. Improbidade administrativa e sua autonomia constitucional. Belo Horizonte: Fórum, 2009. p.160.

${ }^{19}$ ARAUJO, Oliveira Marília. op.cit.

${ }^{20}$ CAPEZ, Fernando. Limites Constitucionais à Lei De Improbidade. São Paulo: Saraiva, 2009. 
${ }^{21}$ NETTO, Orivaldo Bernardes de Oliveira. Quem tem medo do Ministério Público? A aplicabilidade da Lei n. 8.429/1992 a agentes políticos. Boletim Científico ESMPU, Brasília, a. 10 - n. 36, p. 79-100 - Edição Especial 2011. Disponível em: <http://boletimcientifico.escola.mpu.mp.br/boletins/boletimcientifico-n-36-edicao-especial-2011/quem-tem-medo-do-ministerio-publicoa-aplicabilidade-da-lei-n-8-429-1992-a-agentes-politicos >. Acesso em: 12 jul. 2015.

${ }^{22}$ COMPARATO, Fabio Konder. Ação de improbidade: Lei n. 8.429/1992. Competência ao Juízo do $1^{\circ}$ Grau. Disponível em: < http:// portal.damasio.com.br/Arquivos/Material/Parecer\%20improbidade.pdf>. Acesso em: 10 jul. 2015.

${ }^{23}$ OLIVEIRA, José Roberto Pimenta. op. cit. p. 414.

${ }^{24}$ FERNANDES MOÇA, Ricardo Benetti. O retorno da polêmica do foro por prerrogativa de função nas ações por ato de improbidade administrativa. Revista Brasileira de Direito Público - RBDP, Belo Horizonte, ano 11, n. 43, out./dez. 2013. Disponível em: <http://www.bidforum.com.br/bid/ PDI0006.aspx?pdiCntd=98874>. Acesso em: 17 dez. 2014.

${ }^{25}$ GARCIA, Emerson. O combate à corrupção no Brasil: responsabilidade ética e moral do Supremo Tribunal Federal na sua desarticulação. Revista Brasileira de Direito Constitucional - RBDC n. 10 - jul./dez. 2007. Disponível em: <http://www.esdc.com.br/RBDC/RBDC-10/RBDC-10-383Emerson_Garcia.pdf>. Acesso em: 18 jul. 2015.

${ }^{26}$ COMPARATO, Fabio Konder. op.cit.

${ }^{27}$ PIETRO, Maria Sylvia Zanella di. Direito Administrativo. 27. ed. São Paulo: Atlas, 2014. p. 906.

${ }^{28}$ WALD, Arnold; MENDES, Gilmar Ferreira. Competência para julgar ação de improbidade administrativa. Disponível em: <http://www2.senado.leg.br/bdsf/ bitstream/handle/id/378/r138-17. pdf?sequence=4>. Acesso em: 10 jul. 2015.

${ }^{29}$ BRASIL. Lei n. 8429, de 2 de junho de 1992. Dispõe sobre as sanções aplicáveis aos agentes públicos nos casos de enriquecimento ilícito no exercício de mandato, cargo, emprego ou função na administração pública direta, indireta ou fundacional e dá outras providências. Lei de Improbidade Administrativa. Brasília. Disponível em: <http://www.planalto.gov.br/CCivil_03/ leis/L8429.htm>. Acesso em: 10 nov. 2014.

${ }^{30}$ MELLO, Celso Antônio Bandeira de.Curso de Direito Administrativo. 26. ed. São Paulo: Malheiros, 2009.

${ }^{31}$ PIETRO, Maria Sylvia Zanella di. op.cit.. 32 MEIRELLES, Hely Lopes. Direito Administrativo Brasileiro. 33. ed. São Paulo: Malheiros, 2007 
${ }^{33}$ NETTO, Orivaldo Bernardes de Oliveira. op. cit.

${ }^{34}$ NEVES, Daniel Amorim Assumpção; OLIVEIRA, Rafael Carvalho Rezende. Manual de improbidade administrativa: Direito Material e Processual. 2. ed. São Paulo: Método, 2014.

${ }^{35}$ PIETRO, Maria Sylvia Zanella Di. op cit.. p. 912.

${ }^{36}$ Ibidem. p. 952.

${ }^{37}$ CARVALHO FILHO, José dos Santos. Manual de Direito Administrativo. 27. ed. São Paulo: Atlas, 2014.

${ }^{38}$ BITENCOURT NETO, Eurico. Improbidade administrativa e violação de princípios. Belo Horizonte: Del Rey, 2005.

39 COPOLA, Gina. Quem pode ser sujeito ativo do ato de improbidade administrativa? (Lei federal n. 8.429/1992, art. $2^{\circ}$ ): o enquadramento dos magistrados, dos promotores públicos e dos agentes políticos. Fórum Administrativo - Direito Público - FA, Belo Horizonte, ano 8, n. 89,jul. 2008. Disponível em: <http://www.bidforum.com.br/bid/ PDI0006.aspx?pdiCntd=54331>. Acesso em: 28 jan. 2015.

40 MELLO, Celso Antônio Bandeira de. Competência para julgamento de agentes políticos por ofensa à Lei de Improbidade Administrativa (Lei n. 8.429, de 2.6.1992). Interesse Público IP. Belo Horizonte, n. 42, ano 9, mar./abr. 2007. Disponível em: <http://www.bidforum.com.br/bid/ PDI0006.aspx?pdiCntd=48897>. Acesso em: 17 dez. 2014

${ }^{41}$ GARCIA, Emerson; ALVES, Rogério Pacheco. op.cit.

${ }^{42}$ MARTINS JÚNIOR. Wallace Paiva. Tratado de Direito Administrativo. v. 2. Coordenado por: Adilson Dallari, Carlos Valder do Nascimento e Ives Gandra Martins. São Paulo: Saraiva, 2013. p. 151.

${ }^{43}$ OLIVEIRA, José Roberto Pimenta. op.cit. p. 425-428.

${ }^{44}$ CARVALHO FILHO, José dos Santos. op.cit.

${ }^{45}$ BRASIL. Supremo Tribunal Federal. Reclamação n. 2138, Tribunal Pleno. Relator: Ministro Nelson Jobim. Brasília, DF, 13 de junho de 2007. Dje. 17 abr. 2008.

46 Ibidem.

${ }^{47}$ Ibidem.

${ }^{48}$ BRASIL. Supremo Tribunal Federal. Petição n. 3923. Tribunal Pleno. Relator: Ministro Joaquim Barbosa. Brasília, DF, 13 de junho de 2007. Dje. 26 set. 2008.

${ }^{49}$ Ibidem. 
${ }^{50}$ GARCIA, Emerson. op.cit.
${ }^{51}$ BRASIL. Superior Tribunal de Justiça. Reclamação n. 2790. Corte Especial. Relator: Ministro Teori Albino Zavascki. Brasília, DF, 2 de dezembro de 2009. Dje. 4 mar. 2010.

${ }^{52}$ BRASIL. Supremo Tribunal Federal. Ação Cível Originária n. 2356. Decisão Monocrática. Relator: Ministro Carmen Lúcia. Brasília, DF, 11 de março de 2014. Dje. 18 mar. 2014; BRASIL. Supremo Tribunal Federal. Agravo Regimental no Agravo de Instrumento n. 809338, $1^{\text {a }}$ Turma. Relator: Ministro Dias Toffoli. Brasília, DF, 29 de outubro de 2013. Dje. 24 mar. 2014; BRASIL. Supremo Tribunal Federal. Petição n. 5080, Decisão Monocrática. Relator: Ministro Celso de Mello. Brasília, DF, 28 de junho de 2013. Dje. $1^{\circ}$ ago. 2013.

${ }^{53}$ BRASIL. Supremo Tribunal Federal. Ação Cautelar n. 3585. $2^{\text {a }}$ Turma. Relator: Ministro Celso de Mello. Brasília, DF, 2 de setembro de 2014. Dje. 28 out. 2014.

${ }^{54}$ BRASIL. Supremo Tribunal Federal. Informativo n. 768. Disponível em: <http:/ /www.stf.jus.br//arquivo/informativo/documento/informativo768.htm>. Acesso em: 2 mar. 2015.

${ }^{55}$ BRASIL. Supremo Tribunal Federal. Ação Direta de Inconstitucionalidade n. 2797. Tribunal Pleno. Relator: Ministro Sepúlveda Pertence. Brasília, DF, 15 de setembro de 2005. Dje. 12 dez. 2006.

${ }^{56}$ BRASIL. Superior Tribunal de Justiça. Reclamação n. 12.514. Corte Especial. Relator: Ministro Ari Pargendler. Brasília, DF, 16 de setembro de 2013. Dje. 26 set. 2013.

${ }^{57}$ BRASIL. Supremo Tribunal Federal. Agravo Regimental em Petição n. 3067. Tribunal Pleno. Relator: Ministro Roberto Barroso. Brasília, DF, 5 de agosto de 2014. Dje. 29 ago. 2014; BRASIL. Supremo Tribunal Federal. Agravo Regimental no Recurso Extraordinário n. 377114. $1^{\text {a }}$ Turma. Relator: Ministro Marco Aurélio. Brasília, DF, 5 de agosto de 2014. Dje. 29 ago. 2014; BRASIL. Supremo Tribunal Federal. Agravo Regimental no Agravo de Instrumento n.

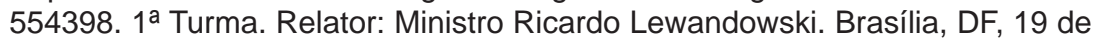
outubro de 2010. Dje. 16 set. 2010.

${ }^{58}$ MIRANDA, Gustavo Senna; COURA. Alexandre de Castro. Extensão do foro por prerrogativa de função às ações de improbidade administrativa. Limites constitucionais para o redimensionamento da competência originária dos tribunais. Revista de Direitos e Garantias Fundamentais da FDV, Vitória, n. 12, dez. 2012. Disponível em: <http://www.fdv.br/sisbib/index.php/ direitosegarantias/article/view/406/150>. Acesso em: 2 mai. 2015.

${ }^{59}$ MARTINS JÚNIOR, Wallace Paiva. op.cit.

${ }^{60}$ FAZZIO JÚNIOR, Waldo. Improbidade administrativa: doutrina, legislação e jurisprudência. São Paulo: Atlas, 2012. p. 438. 
${ }^{61}$ COMPARATO, Fabio Konder. op.cit.

${ }^{62}$ GARCIA, Emerson. op.cit.

${ }^{63}$ WALD, Arnold; MENDES, Gilmar Ferreira. op.cit.

${ }^{64}$ CANOTILHO, José Joaquim Gomes. Direito constitucional e teoria da Constituição. 7. ed. Coimbra- Portugal: Edições Almedina, 2003. p. 549

${ }^{65}$ ALMEIDA, Artur Ferrari; JORDÃO, Eduardo Ferreira. A competência especial por prerrogativa de função para ex-agentes públicos: uma análise do julgamento das ADI n. 2.797DF e n. 2.860DF. Revista Brasileira de Direito Público RBDP. Belo Horizonte. Disponível em: <http://www.bidforum.com.br/ bid/PDI0006.aspx?pdiCntd=52596 > . Acesso em: 17 jul. 2015.

${ }^{66}$ BRASIL. Supremo Tribunal Federal. Informativo n. 768. Disponível em: <http:/ /www.stf.jus.br//arquivo/informativo/documento/informativo768.htm>. Acesso em: 2 mar. 2015. 